\title{
砂の等方圧密およびせん断特性に及ぼす 粒子形状の影響
}

\begin{abstract}
本研究では，砂の粒子形状が圧密およびせん断特性に及ぼす影響を解明するために， 粒度組成が等しく粒子形状のみが異なる試料を用いて等方圧密試験, 排水三軸試験およ び繰返し非排水三軸試験を実施した。 その結果, 内部摩擦角, ダイレイタンシー特性お よび液状化抵抗は粒子形状の違いが大きく影響することが明らかになった．また，等方 圧密時の圧縮指数は初期間隙比によって, せん断初期の剛性を示す変形係数は余裕間隙 比によって一義的に定まることがわかった.
\end{abstract}

Key Words : shear strength, consolidation, grain shape, sand

\section{1.はじめに}

砂の力学的性質は, 土粒子の材質, 粒度組成, 形状な ぞの一次性質および密度, 含水量, 骨組構造なゼの二次 性質によって決定される ${ }^{11}$. 天然に産する砂は土粒子の 材質，粒度組成，形状などの一次性質が異なり，さらに 堆積状況や環境によって二次性質が変化する。これまで の砂の力学的研究の多くは, 特定の砂を用いて二次性質 あるいは試験条件を変化させて行われてきた。しかしな がら，わが国ではロックフィルダム，海中ケーソンのマ ウンドなどの粗粒材料を用いた巨大構造物がこれまでに 数多く建設されてきており, 近年になって, これらの巨 大構造物の変形量や安定度を把握するために，粗粒材料 の変形・強度特性を正確に評価するための研究が行われ てきている2,3). しかし，一般には粗粒材料では設備が 大規模になるなどの理由からその力学的性質を実験に よって解明することは困難であるため，一次性質の異な る砂質土を用いて力学的性質に及ぼす影響を明らかに し，粗粒材料の性質を推定することが期待されている.

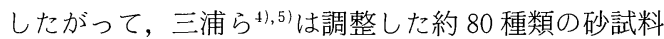
および約 60 種類の自然砂の変形・破壊挙動に及ぼす砂 粒子の粒度分布，粒子形状および破砕性などの影響を明 らかにしている. また，粗粒材料については主に粒子の 破砕性に着目した, 最大粒径が強度に及ぼす影響につい ての研究成果が若干報告6)されてきている。しかしなが ら, 均等係数, 粒子形状に着目した研究はほとんどなく, 上述した研究においても粒径, 均等係数, 粒子形状など の一次性質の独立した各因子が力学的特性に与える影響 についての系統的な研究は行われていない.

そのために筆者ら ${ }^{7)}$ は，粒径，均等係数，粒子形状の

* 正会員 工修 岐皁工業高等専門学校講師 環境都市工学科 (云501-04 本巣郡真正町上真桑 2236-2)

**正会員 工博 長岡技術科学大学教授 工学部建設係
各因子がせん断特性に及ぼす影響を明らかにするため に，調整した堅硬な試料を用いて低圧条件 $\left(\sigma_{c}=49 \mathrm{kPa}\right)$ で三軸 $\mathrm{CD}$ 試験を実施し，粒子破砕がないときにはせん 断特性に及ぼす粒径および均等係数の影響は小さく，粒 子形状の影響が極めて大きいという結果を得ている．ま た，Wong $ら^{8)}$ によると液状化強度は，平均粒径が 0.1 $\mathrm{mm}$ 前後の細砂が最も小さい液状化抵抗を示すものの粒 径の影響をあまり強く受けないと言われており，吉見9 によると細粒土分の少ない自然砂では液状化抵抗力への 均等係数の影響も大きくないことが示されている．さら に, Hatanaka ら ${ }^{10}$ はしらすは粒子が角張っているので 低い密度で堆積しやすいが, 密度の低いわりには液状化 抵抗が大きいことを報告している.

以上のことを考慮し, 本研究では砂の一次性質のうち の特に粒子形状に着目し, 飽和砂の密度を種々に変化さ せたときの等方圧密および排水せん断特性, 液状化抵抗 に及ぼす粒子形状の影響を検討している。

\section{2. 試料および実験方法}

\section{（1）粒子形状の定量化}

土質工学の分野においては粒状体の形状を定量化する ために, Wadell1' の提案した粒子の円磨度を表す roundness, Lees ${ }^{121}$ の提案した粒子の角張りの度合を表 す angularity あるいはこれらの視覚印象図 ${ }^{13,121}$ が時々 利用されてきた。しかし，これらの方法では形状の定量 化の作業がかなり煩雑であったり，個人誤差が入り易い なビの問題があり，粒子形状の定量化法に関しては土質 工学会でも未だ基準化されていない。したがって, 本研 究では筆者ら ${ }^{1+)}$ の提案している凹凸係数 $F U$ を用いて粒 子形状を表した。この $F U$ は，粒子内に直交する三軸を 考え, 図一1 に示すようにその長軸之中間軸を含む平面 に粒子を投影した断面の外周長を $\ell$, 断面積を $a$ とした ときに, 


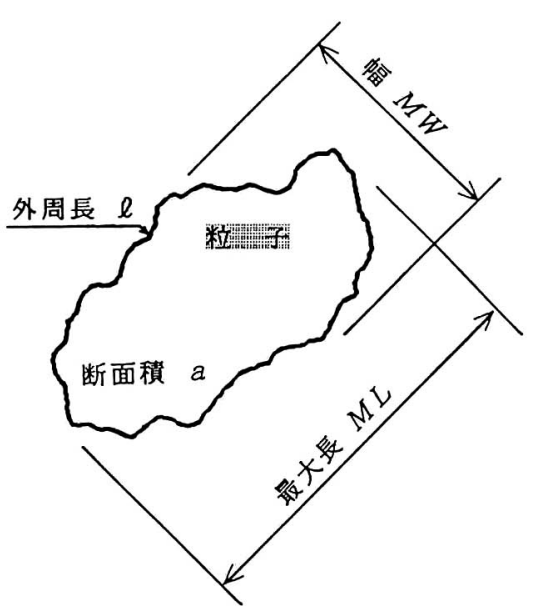

図一1粒子の投影断面模式㘡

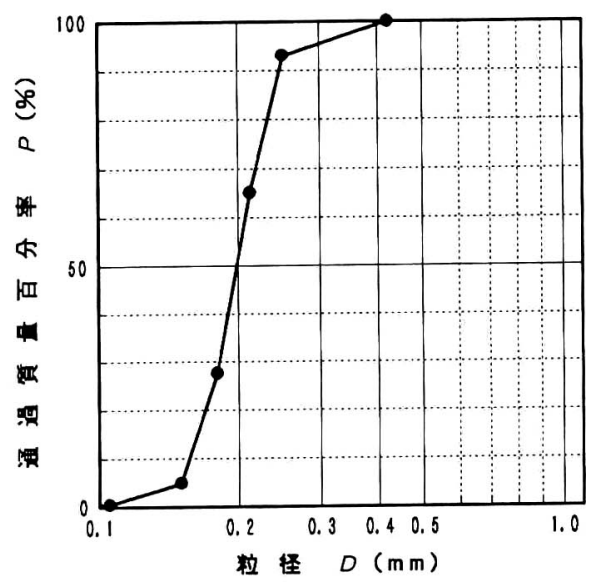

図一2 試料の粒径加積曲線

$F U=4 \pi a / \ell^{2}$

で定義され，粒子が完全球（投影断面が円）の場合に

1.0 で, 凹凸の度合いが激しくなるほど小さくなる係数 である。

\section{（2）実験に用いる試料}

実験に用いる試料は, 粒子形状以外の性質を等しくそ ろえる必要があるので, JSF 基準151に定められている 方法では, 網ふるいのメッシュ幅が粗く母材の異なる砂 の粒度分布を完全に等しく調整するには不十分であるの で,JISの全標準網ふるいを用いて細かいメッシュ幅で ふるい分けを行った. その結果として母材の異なる四種 類（Glass Beads, 豊浦標準砂, 木兽川砂, 砕砂) の粒 状体の粒度分布を図一2のように調整することができ た.なお，各材料の粒子の断面形状は写真一1 に示す之 おりである.ここで, 木曽川砂は現木曽川河川敷きの堆 積砂では最上流部にあたる愛知県犬山市のライン大橋下 流の右岸側から採取した砂であり, 形状はかなり角張っ ている．砕砂は岐阜県揖斐郡谷汲村長瀬産の頁岩をク

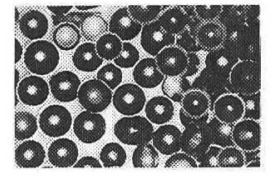

(a) Glass Beads

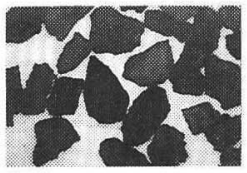

（c）木曾川砂

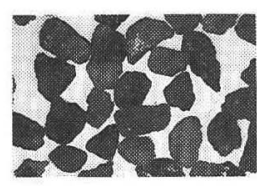

(b ) 豊浦標準砂

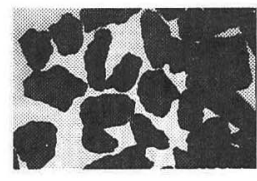

(d) 砕 砂

$1.0 \mathrm{~mm}$
写真一1 試料の光学顕微境写真

表一1 試料の性質

\begin{tabular}{|l|c|c|}
\hline & $F U$ & $\rho_{\mathrm{s}}\left(\mathrm{g} / \mathrm{cm}^{3}\right)$ \\
\hline Glass Beads & 0.908 & 2.495 \\
\hline 豊浦楅準砂 & 0.745 & 2.637 \\
\hline 木曾川砂 & 0.689 & 2.682 \\
\hline 砕 砂 & 0.644 & 2.750 \\
\hline
\end{tabular}

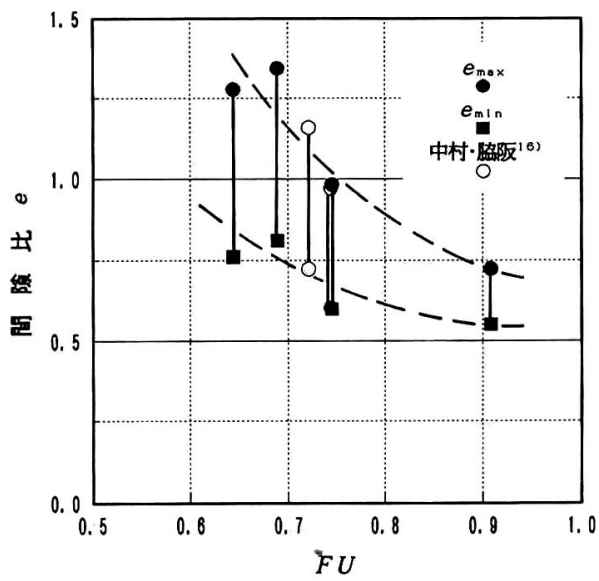

図一3 最大·最小間隙比と $F U$ の関係

ラッシャーにて破砕したものである.

各試料の材質の硬さはほぼ等しく, モ一ス硬度ではお およそ Glass Beads が 6.5, 豊浦標準砂が 7 , 木曽川砂 が 6.5 , 砕砂が 6.5 であり，いずれも堅硬である。なお, 本研究では粒子表面の粗度については考慮しておらず,

これらの試料の $F U$ と土粒子の密度 $\rho_{s}$ は表一1の上お りである。

また, 図一3 は各試料の最大問隙比 $e_{\max }$, 最小間隙比 $e_{\min }$ と凹凸係数 $F U$ の関係を示しており，おおむね $F U$ が大きくなり形状が丸くなるほど $e_{\max }, e_{\min }$ および間陌 比幅 $\left(e_{\max }-e_{\min }\right)$ は小さくなっている.なお, 図中に は本研究の粒度分布とほぼ等しい海砂および豊浦標準砂 を用いて行われた中村・脇阪 ${ }^{16)}$ の実験報告に，筆者らが 形状测定を追加して求めた間隙比一 $F U$ 関係も併記して 


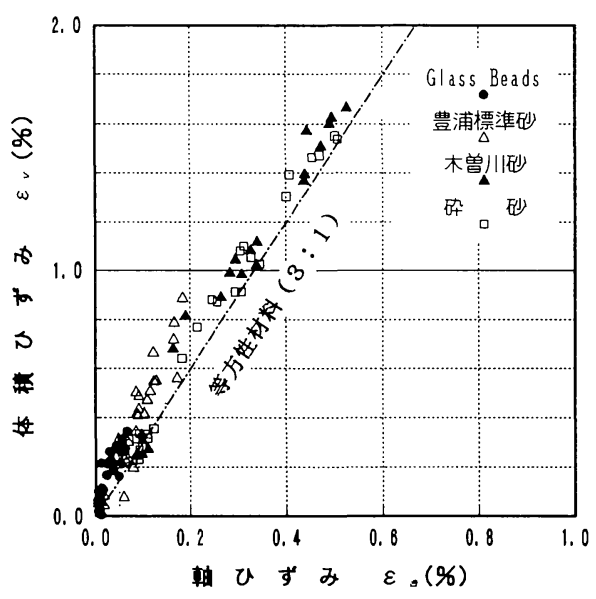

図一4 等方圧密時の体積ひずみと軸ひずみの関係

ある.

\section{（3）実験方法}

試験用の供試体は，筆者らが考案した落下装置》を使 い, 乾燥試料を用いて空中落下方式により直径 $50 \mathrm{~mm}$, 高さ $100 \mathrm{~mm}$ に作成した。

供試体寸法は, $29.4 \mathrm{kPa}$ の負圧を作用させて測定し, これを供試体の初期状態 $\left(e_{0}, D_{r 0}\right)$ とした. 拘束圧 $\sigma_{c}^{\prime}$ $=29.4 \mathrm{kPa}$ として脱気水を通水させ，供試体を飽和さ せた後バックプレッシャーB. P. $=196 \mathrm{kPa}$ を气，B 係数が 0.98 以上であることを飽和の条件とした。排水 三軸圧縮試験は所定の等方圧密圧力 $p^{\prime}=\sigma_{c}{ }^{\prime} \quad(49,98$, $147 \mathrm{kPa}$ ）で圧密した後，ひずみ制御方式（ひずみ速度 $0.25 \% / \mathrm{min}.)^{7}$ の拘束圧一定の CD 試験とした。また， 繰返し非排水三軸試験は有効拘束圧 $\sigma_{c}{ }^{\prime}=49 \mathrm{kPa}$, 繰返 し載荷は周波数 $f=0.1 \mathrm{~Hz}$ の正弦波で偏差応力 $\sigma_{d}$ は第 1 波めを圧縮側から載荷する全国一斉試験 ${ }^{17}$ に従った。

なお，本研究での拘束圧の範囲では一回の試験前後の 粒度分布には差が見られず，これまでの粒子破砕性の評 価指標 ${ }^{18)}$ の多くが試験前後の粒度分布の相違に準拠して いることから，本研究ではせん断中の粒子破砕はないも のと考えた。しかしながら，その蓄積を避けるために試 料は使い捨てとし繰返し使用は避けた。

\section{3． 等方圧密特性}

各試料のゆる詰め $\left(D_{r 0} \doteqdot 30 \%\right)$ 少ら密詰め $\left(D_{r 0} \doteqdot 80 \%\right)$ におよぶ供試体を初期等方圧力 $\sigma_{c}{ }^{\prime}=29.4 \mathrm{kPa}$ から等方 圧力 $p^{\prime}$ を 49 147 kPa（ただし，豊浦標準砂は 49２94 $\mathrm{kPa}$ ）まで増大させて等方圧密したときの圧密終了後の 体積ひずみ $\varepsilon_{v}$ と軸ひずみ $\varepsilon_{a}$ の関係を図一 4 に示す. 図 中の一点鎖線は等方性材料の挙動である $\varepsilon_{v}=3 \varepsilon_{a}$ の関係 であり，これに比べ各試料とも $\varepsilon_{v}$ が若干大きめである が，この範囲内の挙動をみると各試料ともほぼ等方性を 示しているといえる。ただし，膨潤試験，再載荷試験は
実施していないので各試料が弾性挙動を示すか否かの検 討は行っていない. この $\varepsilon_{v}=3 \varepsilon_{a}$ の関係は, 初期構造異 方性を判断するための 1 つの指標であるとともに, 異方 性のない供試体ではこの関係から等方圧密中のメンブレ ン貫入量を推定することが可能である. 図一4に示され る $\varepsilon_{v}=3 \varepsilon_{a}$ と測定値の差には構造異方性とメンブレン貫 入量の両方の影響が含まれるものの本実験ではその差は それほぼ大きくないこと, 試料の平均粒径 $D_{50}$ は図一2 の亡おり約 $0.2 \mathrm{~mm}$ で供試体直径の約 $1 / 250$ 上極めて小 さい己とから判断して, 本研究では等方圧密時の体積変 化に対するメンブレン貫入量の補正は行っていない。

三浦 ${ }^{19}$ は豊浦標準砂を用いた等方圧密試験より，高圧 下になると粘性土の圧密降伏応力に相当する折点をもつ $e-\log p^{\prime}$ 曲線が求まるが, この折点以上の応力レベルで 生じる塑性的な体積圧縮および時間依存性挙動は, 主に 粒子破砕によるものであると述べている，さらに，三浦 $ら^{201}$ は豊浦標準砂を含む約 80 種類の砂試料の等方圧密 試験より，少なくとも $196 \mathrm{kPa}$ の応カレベルでは圧密 変形に及ぼす粒子自身の破砕の影響は考慮しなくても良 いことを報告している．本実験の等方圧力条件下での各 試料の $e-\log p^{\prime}$ 関係は図一 5 に示すとおりである.なお, ここでは各図の比較を容易にするために縦軸スケールを 統一してある. 図加ら明らかなように本実験のように応 力が比較的低い範囲であ机ば，圧密時に粒子破砕は生じ ず，龍岡 ${ }^{21}$ の報告之同様に特にゆる詰めの砂であっても 圧縮性は小さく, ゆる詰砂と密詰め砂の間隙比 $e$ の互 いの接近はそれほど顕著ではない．また，いずれの試料 についても供試体の初期状態がゆる詰めから密詰めまで の $e-\log p^{\prime}$ 曲線は直線で回帰することができ, その相 関係数はおおよそ 0.98 以上であった。したがって，空 中落下法によって作成された砂供試体は，粒子破砕のな い応力範囲であれば正規圧密状態の粘性土之類似の $e-$ $\log p^{\prime}$ 関係を示すといえる. 図一5より，各試料の初期 状態毎に圧縮指数 $\lambda\left(=0.434 C_{c}\right)$ を求めると図一6に 示すような $\log \lambda-e_{0}$ 関係となり, $\log \lambda$ と $e_{0}$ の関係はほ ぼ直線で近似することができるので, 圧縮指数は粒度組 成が等しければ材料の粒子形状に差があっても初期間隙 比のみで決定されることがわかる. 各試料の取り得る間 隙比は粒子集合体の構造的な安定性から決まる221ので, 間隙比 $e$ は図一3のように粒子形状に大きく左右される ため，すでに間隙比にはこの粒子形状の影響が含まれて おり，等方圧密のようにダイレイタンシーが生じない体 積収縮のみの場合には初期間隙比から圧縮指数 $\lambda$ が決ま るといえる.

本研究で用いた粒度組成（豊浦標準砂に等しく, 平均 粒径 $D_{50}=0.202 \mathrm{~mm}$, 均等係数 $U_{c}=1.32$, 曲率係数 $U_{c}^{\prime}$ $=1.0)$ の材料での $\lambda$ 之 $e_{0}$ の関係式は次のようになる.

$\lambda=2.09 \times 10^{-4} \times \exp \left(4.31 \cdot e_{0}\right) \cdots$ 


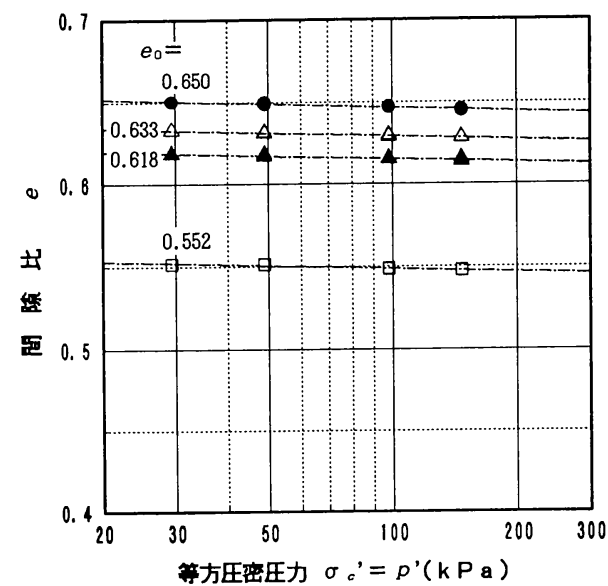

(a) Glass Beads

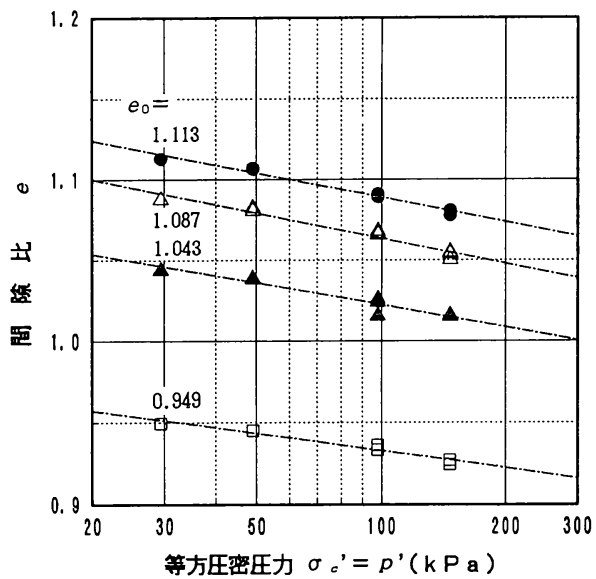

(c) 木曾川砂

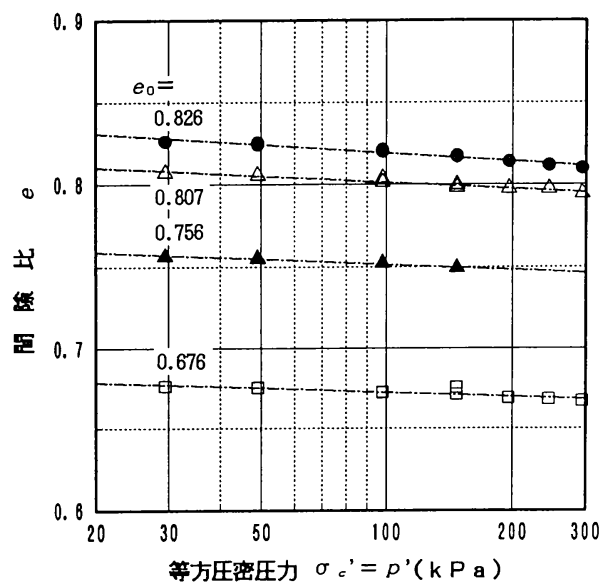

(b) 豊浦標準砂

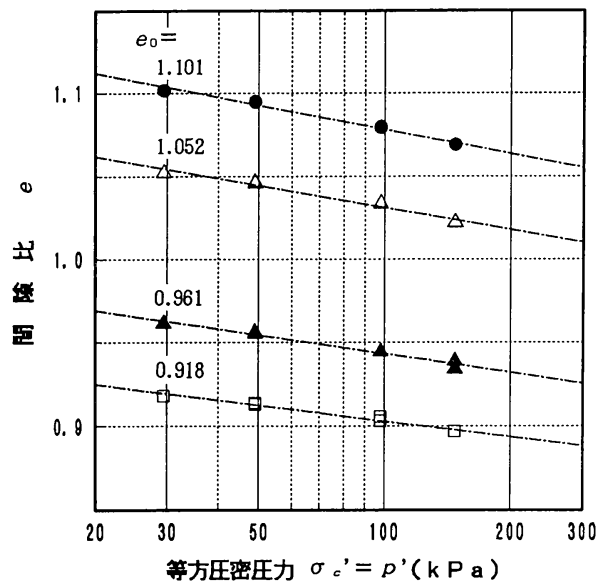

(d) 砕 砂

図一5 $\quad e-\log p$ 曲線

ここに，入は圧縮指数 $\left(=0.434 C_{c}\right), e_{0}$ は初期間隙比 である.

すなわち, 砂の等方圧密特性は初期間隙比に依存し, 粒子形状の影響を受けていないことがわかる.ただし， 圧縮指数は粒度組成 (平均粒径, 均等係数など)の影響も 大きいと考えられるので初期間隙比のみで一義的に決定 することはできない.

\section{4. 排水せん断特性}

三軸試験の実験デー夕を整理する場合, 軸差応力 $q$ あ るいは主応力比 $R$ と軸ひずみ $\varepsilon_{a}$ の関係をプロットする のが一般的であるが，これらの関係から直感的にせん断 強さおよび変形係数両者の拘束圧依存性を判断するのは 難しい，そこで本論文では，縦軸に拘束圧力で正規化し た軸差応力 ${ }^{23)}$ ，すなわち $q / \sigma_{c}{ }^{\prime}$ をとり，これと軸ひずみ $\varepsilon_{a}$ との関係を示している.

$\sigma_{c}{ }^{\prime}=49 \mathrm{kPa}$ での CD 試験で，異なる $D_{r 0}$ を有する砕

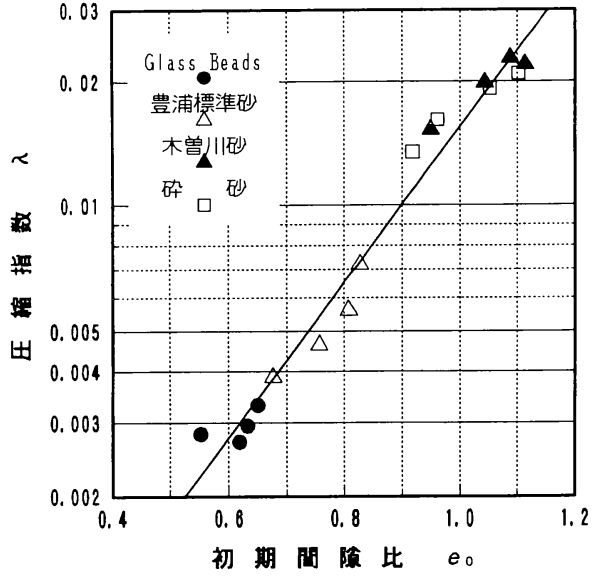

図一 6 圧縮指数之初期間隙比の関係

砂の $q / \sigma_{c}{ }^{\prime}-\varepsilon_{a}$ 関係および体積ひずみ $\varepsilon_{v}-\varepsilon_{a}$ 関係は図一 7 のとおりであり, 他の試料についても従来の研究と同 様に密度の増加に伴う強度, 剛性, ダイレイタンシー量 


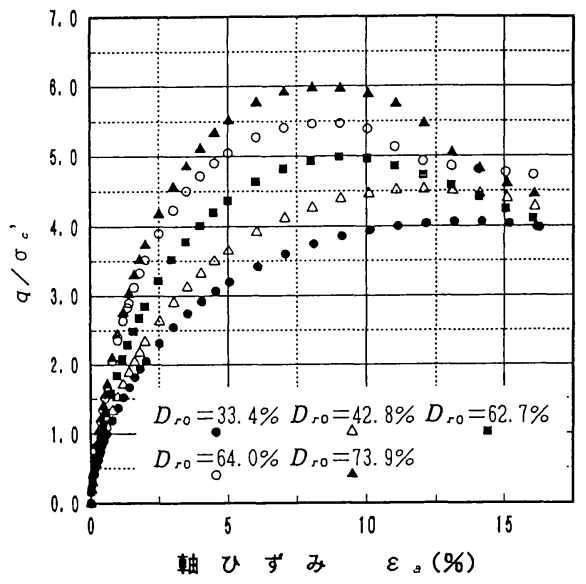

(a) $q / \sigma \stackrel{\sigma}{a}-\varepsilon$ 関係

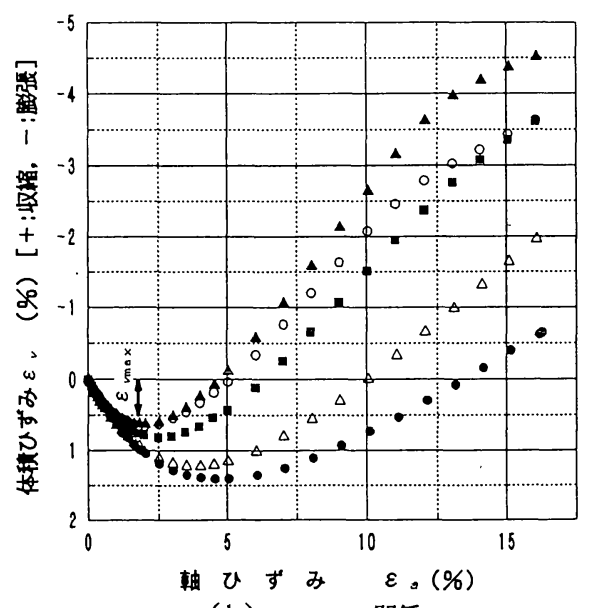

(b) $\varepsilon_{v}-\varepsilon$, 関係

図一7 砕砂の実験結果例 $\left(\sigma_{c}{ }^{\prime}=49 \mathrm{kPa}\right)$

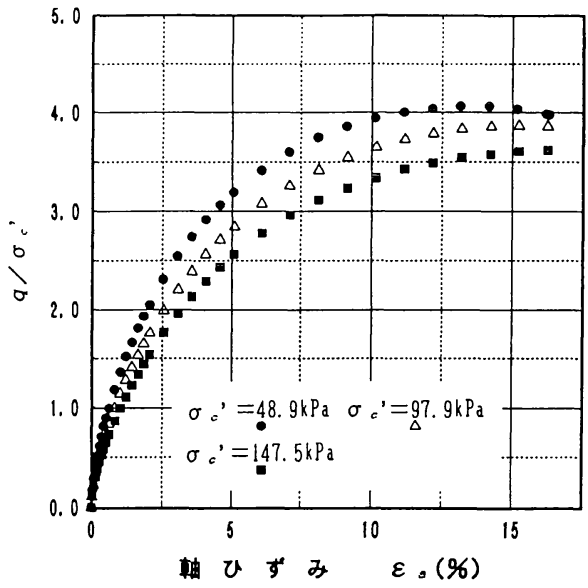

(a) $q / \sigma_{c}^{\prime}-\varepsilon$ 。関係

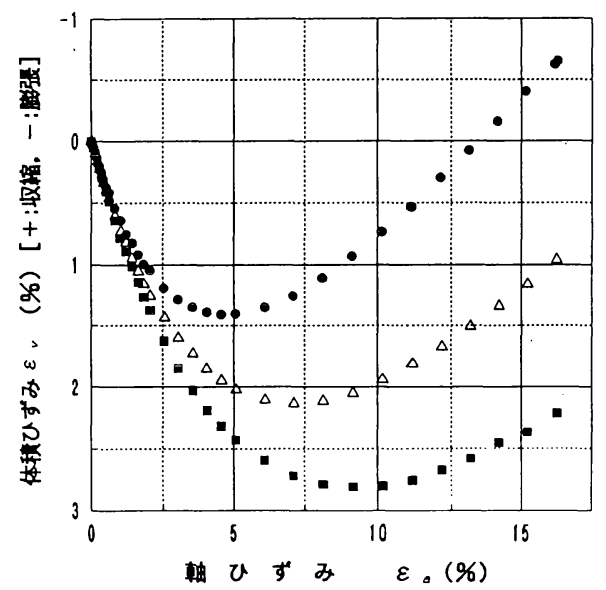

(b) $\varepsilon_{v}-\varepsilon$ 関係

図一8 ゆる詰めな砕砂の実験結果例 $\left(D_{r 0}=33.3 \%\right)$
の増加が見られる.なお，本論文では内部摩擦角 $\phi_{d}$ は 動員される最大值, すなわち, $\phi_{d}=\sin ^{-1}\left\{\left(\sigma_{1}-\sigma_{3}\right) /\left(\sigma_{1}\right.\right.$ $\left.\left.+\sigma_{3}\right)\right\}_{\max }$, 変形係数 $\overline{E_{50}{ }^{\prime}}$ は図一7 (a)において $\left(q / \sigma_{c}{ }^{\prime}\right)_{\max }$ 12 と原点を結ぶ割線勾配で定義した無次元量である.

また，ゆる詰め $\left(D_{r 0}=33.3 \%\right)$ にした砕砂で拘束圧 $\sigma_{c}{ }^{\prime}$ を変化させたときの $q / \sigma_{c}{ }^{\prime}-\varepsilon_{a}$ および $\varepsilon_{v}-\varepsilon_{a}$ 関係は図 一8のようになり, 変形, 強度特性には拘束圧依存性が 見られる.この拘束圧依存性は, 圧力の増加に伴う粒子 破砕，圧縮時の粒子の移動のし易さなどによるものであ るが, 本研究ではせん断中にほとんど粒子破砕が生じて いないことから，この依存性は主にはダイレイタンシー 特性の差異によるものと考えられる.すなわち，図一8 に見られるように $q / \sigma_{c}{ }^{\prime}$ のピーク付近の体積ひずみ増分 比 $d \varepsilon_{v} / d \varepsilon_{a}$ は $\sigma_{c}{ }^{\prime}$ が大きくなるほど小さくなっており, せん断中の粒子の膨張側への移動がし難くなるために, ダイレイタンシーによる体積膨張が小さくなって変形,
強度特性に影響を及ぼすのである，また，松岡ら"゙は 2 種混合径のアルミ丸棒積層体を用いて一面せん断試験を 実施し, せん断強さ $\tau$ 一鉛直圧力 $\sigma$ 関係が上に凸の曲線, すなわち内部摩擦角はやはり $\sigma$ が大きくなるほど小さ くなることを報告しており，アルミ丸棒のように粒子鋭 角部や粒子自体の破砕のまったく無い材料についても変 形, 強度特性に $\sigma$ 依存性があることが確かめられてい る。

さらに， $\sigma_{c}{ }^{\prime}=49 \mathrm{kPa}$ で実施した中密な状態 $\left(D_{r 0}=\right.$ $57.9 \sim 62.7 \%$ ）における各試料の $q / \sigma_{c}{ }^{\prime}-\varepsilon_{a}$ 関係および $\varepsilon_{v}-\varepsilon_{a}$ 関係を図一 9 に示すが，粒子形状の違いによって も明らかに強度, 剛性, ダイレイタンシー量が異なるこ とがわかる。

以下に, 粒子形状が変形特性, ダイレイタンシー特性 および強度特性のせん断特性に及ぼす影響について述べ る。 

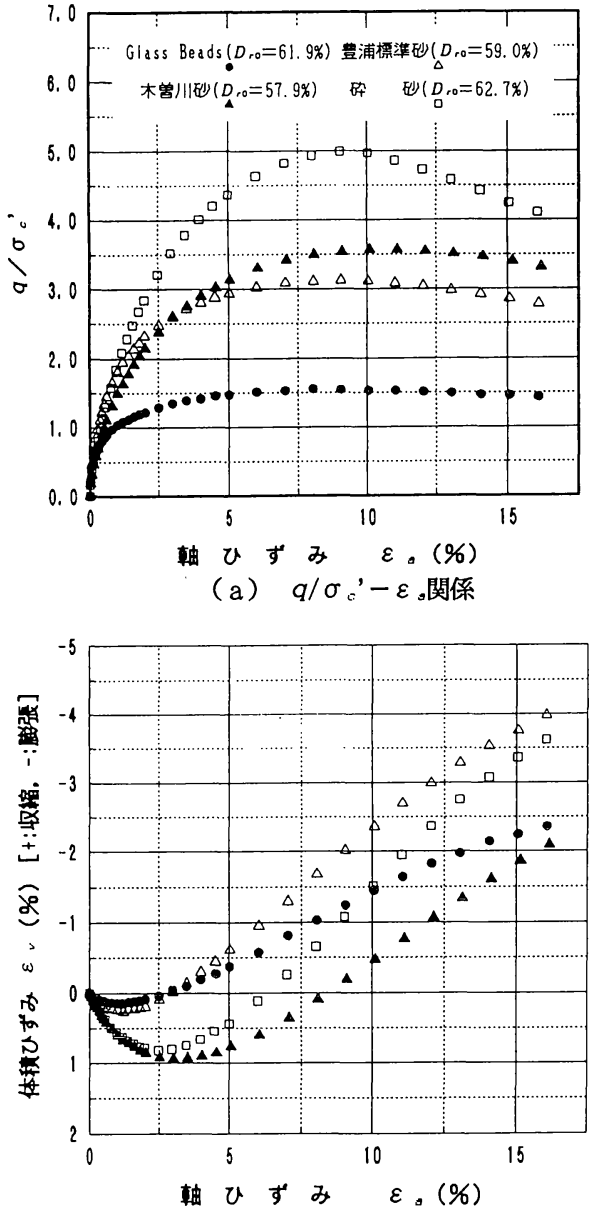

(b) $\varepsilon_{v}-\varepsilon_{\text {。関係 }}$

図一9 中密な供試体の実験結果例 $\left(\sigma_{c}^{\prime}=49 \mathrm{kPa}\right)$

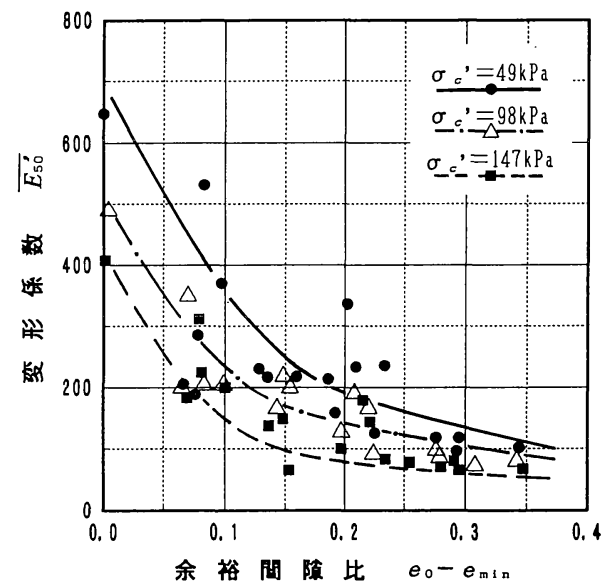

図一10 変形係数と余裕間隙比の関係

\section{（1）変形特性への粒子形状の影響}

変形係数 $\overline{E_{50}{ }^{\prime}}$ は，図一7，8 および 9 の結果からも明 らかなように，密度および拘束圧，さらには粒子形状に

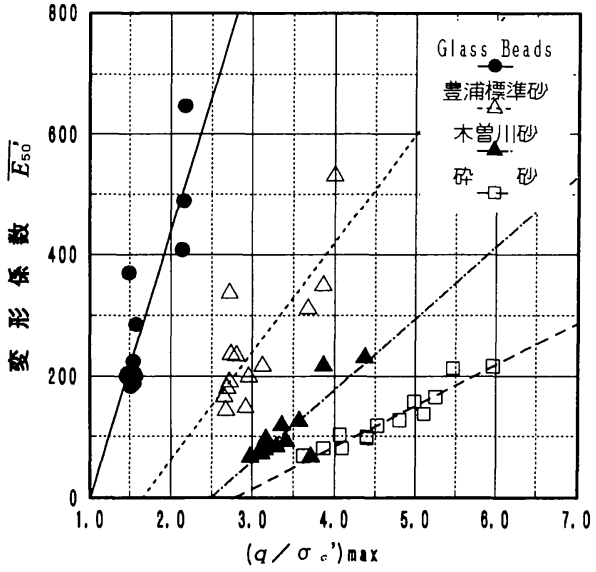

図一11 変形係数之 $\left(q / \sigma_{c}{ }^{\prime}\right)_{\max }$ の関係

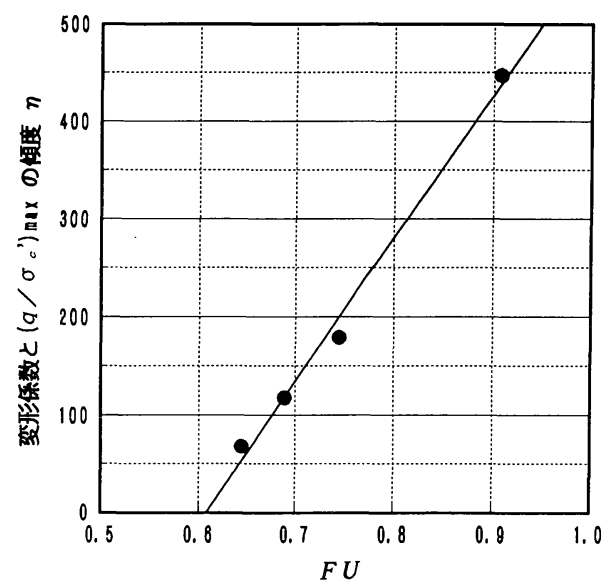

図一12 $\quad \eta$ と $F U$ の関係

依存している。しかし, $\overline{E_{50}}$ は密度, 粒度組成, 粒子形 状には無関係に余裕間隙比 $\left(e_{0}-e_{\min }\right)^{25}$ によって一義的 に定まることが知られている゙が， $\overline{E_{50}}$ 亡 $\left(e_{0}-e_{\min }\right)$ の 関係は図一10 に示すとおりであり，拘束圧が大きくな ると剛性はやや低下している.

さらに，実験を行った全拘束圧について $\overline{E_{50}{ }^{\prime}}$ と $\sigma_{c}{ }^{\prime}$ で 正規化した最大軸差応力 $\left(q / \sigma_{c}{ }^{\prime}\right)_{\max }$ の関係は図一11の ようになり，両者の間には粒子形状の異なる試料毎にほ ぼ比例関係が認められる。これは図一8あるいは図一10 にみられる $\overline{E_{50}{ }^{\prime}}$ の拘束圧依存性に矛盾するが，一方で は図一8のように $\left(q / \sigma_{c}{ }^{\prime}\right)_{\max }$ にも拘束圧依存性があり, この両者の拘束圧の依存度がほぼ同程度であるために図 -11 のような関係になるものと考えられる。この直線 の傾き クは粒子形状が丸い試料ほざ大きくなっており, $\eta$ 亡凹凸係数 $F U$ の関係は図一 12 の上うにほぼ直線関 係にあるので, 強度変化に対する $\overline{E_{50}{ }^{\prime}}$ の変化量は $F U$ にほぼ比例しているといえる.

\section{（2）ダイレイタンシー特性への粒子形状の影響}

$\mathrm{Rowe}^{26)}$ が導いた式（3）で与えられるストレス $R$ - 


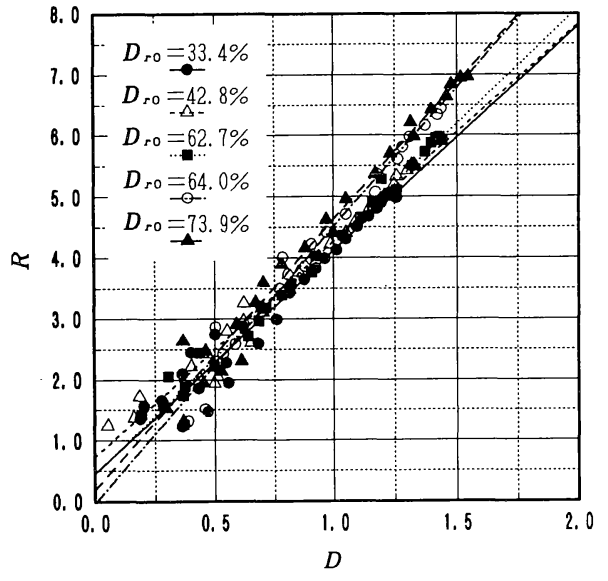

図-13 砕砂の $R-D$ 関係 $\left(\sigma_{c}^{\prime}=49 \mathrm{kPa}\right)$

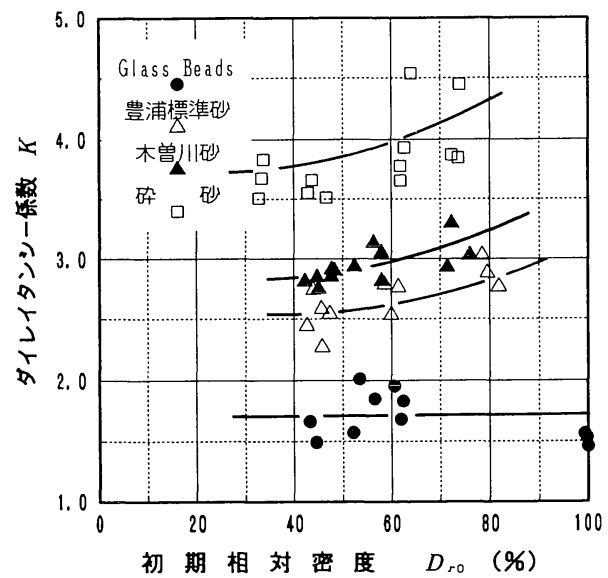

図一14 $K$ と初期相対密度の関係

ダイレイタンシー $D$ 関係を用いてダイレイタンシー特 性と粒子形状の関係を検討する.

$R=K \times D \cdots$

ここに, $R$ : 応力比 $\left(\sigma_{1} / \sigma_{3}\right), K$ : ダイレイタンシー係数, $D:$ 主ひずみ増分比 $\left(-2 d \varepsilon_{3} / d \varepsilon_{1}=1-d \varepsilon_{v} / d \varepsilon_{a}\right)$ である.

$\sigma_{c}{ }^{\prime}=49 \mathrm{kPa}$ で実施したせん断中の砕砂の $R-D$ 関係 を示す図一13をみると, 若干の密度依存性および切片

(定数項) が見られる.このような $R-D$ 関係は有効 拘束圧 $\sigma_{c}{ }^{\prime}$ が変化しても試料が異なっても図一13 と同様 の傾向にあり, 拘束圧依存性も認められなかった。した がって, $R-D$ 関係はすでに小田 ${ }^{27)}$ が内部構造変化の微 視的な考察によって説明しているように次式のような一 般式で表すことができる.

$R=K^{\prime} \times D+C$.

しかしながら, 本研究ではどの試料も図一13に示され るように切片 $C$ は小さいので, 式 $(4)$ の切片 $C$ をほ ぼ零と考え, ここではダイレイタンシー係数 $K$ にい て考察する.

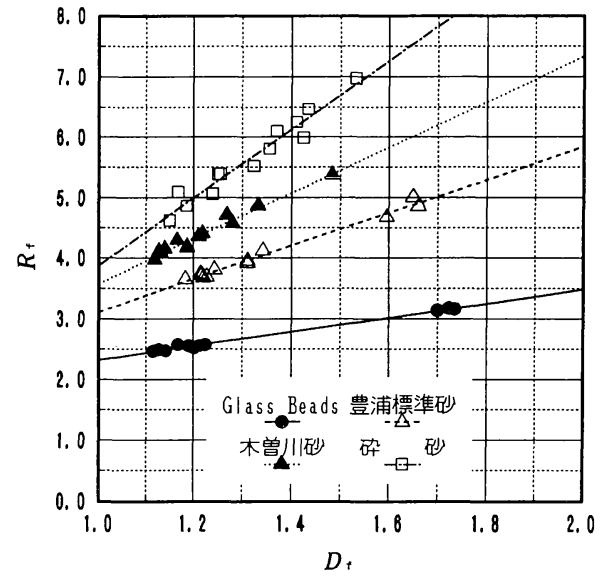

図一15 破壞時の $R_{f}-D_{f}$ 関係

各試料の全ての拘束圧について求めた $K$ を初期相対 密度 $D_{r 0}$ との関係で整理すると図一14のようになり, せん断中のストレスーダイレイタンシー関係は粒子形状 に大きく影響されることがわかる。また，若干ではある が $K$ には密度依存性も認められる。したがって，せん 断中の主応力比の変化に対する体積の変化量は, 粒子が 角張っているほよ゙，さらには密なほど大きいといえる.

一方, 破壊時のストレス $R_{f}$-ダイレイタンシー $D_{f}$ 関 係は図一15のとおりであり, 破壊時においても前述の せん断中の $R-D$ 関係之類似の傾向が認められ，しか も密度による差は見られなかった。したがって， $R_{f}$ $D_{f}$ 関係の傾度である破壊時のダイレイタンシー係数 $K_{f}$ は土の状態に関係のないその土質に固有の定数であり， 粒子形状が丸くなるほど $K_{f}$ は小さくなる，さらに，こ の関係は筆者ら ${ }^{7)}$ の研究によれば粒度組成（粒径, 粒度 分布）にも無関係であり, 粒子形状のみによって決まる 関係である.ただし，この係数 $K_{f}$ は図一14に示したせ ん断途中の $K$ の値に比べて, 若干大きくなっている.

\section{（3）内部摩擦角への粒子形状の影響}

内部摩擦角 $\phi_{d}$ と初期相対密度 $D_{r 0}$ との関係は図一16 に示すとおりであり， $\phi_{d}$ は粒子形状の影響を大きく受 けており，また密度および拘束圧依存性も認められる.

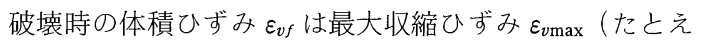
ば図一7（b）参照）に達した後は吸水し, 膨張（正の ダイレイタンシー）に転じる.したがって, 図一7 (b) および図一8 (b) の $\varepsilon_{v}-\varepsilon_{a}$ 関係から明らかなように同 一試料のー $\varepsilon_{v f}$ は $D_{r 0}$ が大きいほど大きく, また有効拘 束圧 $\sigma_{c}{ }^{\prime}$ が小さいほぼ大きいので, この破壊時のダイレ イタンシー量から $\phi_{d}$ の密度および拘束圧依存性が生じ る. また, $\phi_{d}$ は粒子が丸く $F U$ が大きく, 密度が小さ くなるほよ゙小さく,さらに拘束圧の増加に伴って減少し, その減少率は粒子が角張っているほど大きい。さらに, $\sigma_{c}{ }^{\prime}=49 \mathrm{kPa}$ の場合の中密 $\left(D_{r 0}=50 \%\right)$ 状態の $\phi_{d}$ と 


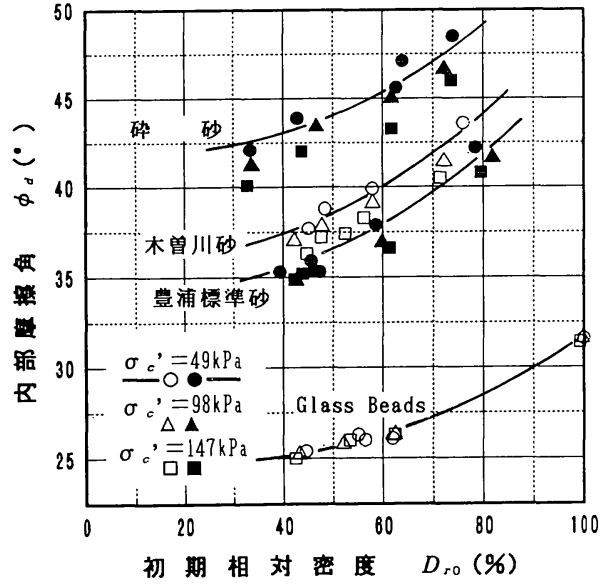

図一16 内部摩擦角之初期相対密度の関係

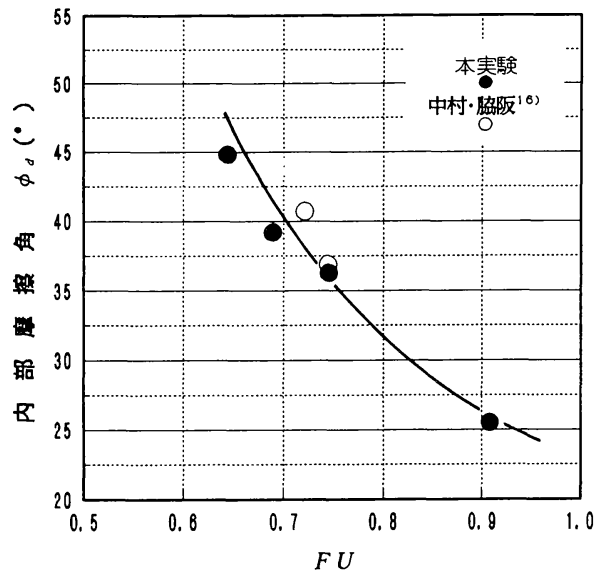

図一17 内部摩擦角と $F U$ の関係 $\left(D_{r 0}=50 \%\right)$

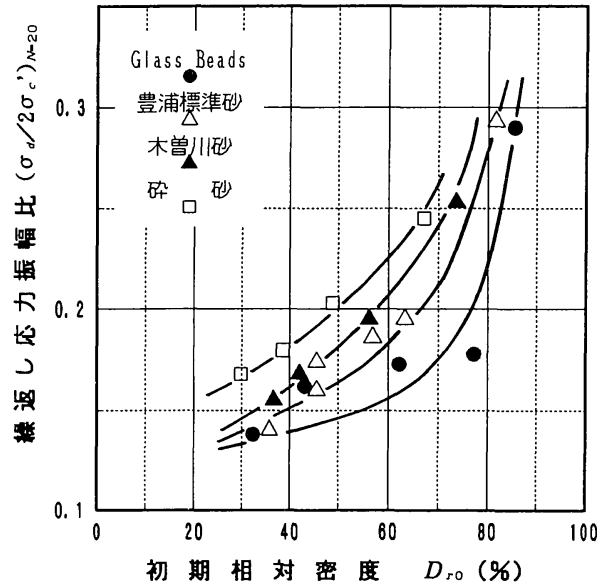

図一18 繰返し振幅比と初期相対密度の関係 $(D A=10 \%)$

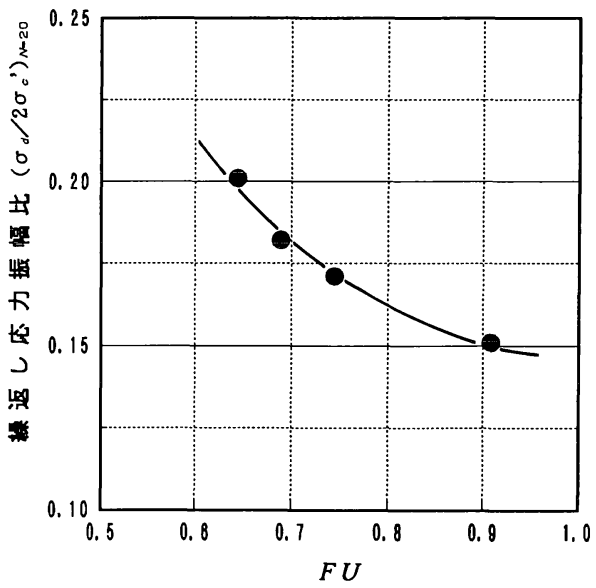

図一19 繰返し振幅比と $F U$ の関係 $(D A=10 \%)$
$F U$ の関係は図一17のとおりであり，前述した $\phi_{d}$ に及 ぼす粒子形状の関係が明らかである。なお，図中には図 -3之同様に中村・脇阪 ${ }^{16)}$ の実験データも併記してあ る、筆者 ${ }^{28)}$ の調查によれば，わが国の典型的な神積平野 である濃尾平野の木曽三川流域から採取した約 170 種の 河川堆積砂は, $F U=0.669 \sim 0.826$ 程度の幅があり，し たがって図一17からわかるように天然の砂でも粒子形 状の違いのみで $\phi_{d}$ は約 $15^{\circ}$ も変化することになり, 試 料がゆる詰め状態から密詰め状態に変化しても $\phi_{d}$ は約 $5^{\circ} \sim 8^{\circ}$ 増加する程度であるのに比べて, 砂の内部摩擦角 に及ぼす粒子形状の影響は極めて大きいといえる.

\section{5. 液状化抵抗への粒子形状の影響}

Seed and Lee ${ }^{299}$ によば，「液状化とは土が急激に広 いひずみの範囲にわたって変形に対する抵抗力を失うこ と, すなわち, 砂の場合には有効拘束圧が零になった状 態」と定義されているが，これまでの砂の非排水繰返し 三軸試験における液状化抵抗は, $\Delta u / \sigma_{c}{ }^{\prime}=0$ となる以前
の，たとえば軸差応力が増加しているにもかかわらず間 隙水圧が凹む, いわゆる凹み現象 (飛び出し現象) がみ られる状態，軸ひずみが急増する状態などの初期液状化 状態を液状化発生の基準 ${ }^{30), 31)}$ とするか，あるいは全国一 斉試験 ${ }^{17)}$ で提案されたようにある大きさの両振幅軸ひず み $(D A)$ に達した状態のいずれかにより検討されている. 本研究では種々の方法でデー夕整理を行ったが, 液状化 抵抗に及ぼす粒子形状の影響を検討するにはいずれの方 法によっても同じ傾向を示したので，ここでは両振幅軸 ひずみ $D A=10 \%$ に達したときを液状化状態に達したも のとした.

一連の実験結果の繰返し応力振幅比 $\left(\sigma_{d} / 2 \sigma_{c}{ }^{\prime}\right)$ と繰 返し載荷回数 $N_{c}$ の関係より, $N_{c}=20$ 回で液状化状態 となる $\left(\sigma_{d} / 2 \sigma_{c}{ }^{\prime}\right)_{N=20}$ と相対密度 $D_{r 0}$ との関係をみると 図一18 となり，液状化抵抗は粒子が丸くなる試料ほよ゙ 小さくなることがわかる，いま，中密 $\left(D_{r 0}=50 \%\right)$ 状 態の $\left(\sigma_{d} / 2 \sigma_{c}{ }^{\prime}\right)_{N=20}$ と $F U$ との関係をみると図一19 とな り, $\phi_{d}$ と $F U$ の関係を示す図一17 とを比較すると両者 


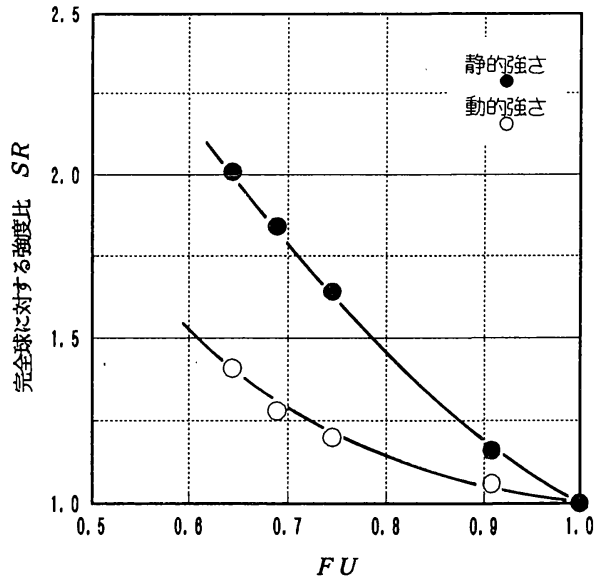

図一20 強度比 $S R$ と $F U$ の関係

の関係には類似性がある．そこで $\phi_{d}$ および $\left(\sigma_{d} / 2 \sigma_{c}{ }^{\prime}\right)$ の粒子形状に対する敏感さをみるために, この両図から 各々外插により $F U=1.0$ (粒子が完全球) の場合の $\phi_{d}$ および $\left(\sigma_{d} / 2 \sigma_{c}{ }^{\prime}\right)$ を求め, それぞれ各試料の値との比 $(S R)$ をとって $F U$ の関係を示すと図一20となり, 動的強さ に比較して静的強さのほうが粒子形状の影響を大きく受 けることがわかる.

\section{6. 結 論}

本研究では三軸試験機を用いて等方圧密, 拘束圧一定 の排水せん断試験および繰返し非排水試験を実施し, 飽 和砂の密度を種々に変化させたときの圧密および排水せ ん断特性, 液状化抵抗に及ぼす粒子形状の影響を明らか にした.

本研究によって得られた主要な結果をまとめると, 以 下のよおりである.

（1）砂を等方圧密すると粒子破砕のない応力範囲であ れば正規圧密状態の粘性土と類似の $e-\log p^{\prime}$ 関係を示 す.また，その傾度である圧縮指数は粒子形状に無関係 に初期間隙比 $e_{0}$ により一義的に決まる.

(2) 変形係数 $\overline{E_{50}{ }^{\prime}}$ は, 拘束圧に依存するものの粒子 形状には依存せず, 余裕間隙比 $\left(e_{0}-e_{\min }\right)$ によって一 義的に定まる. また，この変形係数と拘束圧で正規化し た最大軸差応力 $\left(q / \sigma_{c}{ }^{\prime}\right)_{\max }$ の関係には拘束圧依存性は なく, 試料毎に比例関係があり，その傾度は粒子形状が 丸くなるほど大きく, 凹凸係数 $F U$ との間にほぼ直線性 が認められる。

(3) Rowe $\mathrm{e}^{26)}$ の提案したせん断中のストレス $R$ 一ダイ レイタンシー $D$ 関係は粒子形状に大きく影響を受け, この傾度であるダイレイタンシー係数 $K$ は粒子形状が 丸くなるほど小さく, 若干の密度依存性が認められる. また, 破壊時のストレス $R_{f}$ 一ダイレイタンシー $D_{f}$ 関係 も粒子形状に大きな影響を受け，その関係はせん断中の
$R$ 一 $D$ 関係亡類似であり，このダイレイタンシー係数 $K_{f}$ は粒子形状が丸くなり $F U$ が大きくなるほど小さく なる.さらに，破壊時の $K_{f}$ はせん断途中の $K$ の値に比 ベて若干大きい.

（4）内部摩擦角 $\phi_{d}$ は粒子形状が丸くなるほぼ，また 密度が小さくなるほぼ小さく，さらに拘束圧の増加に 伴って減少し，その減少率は粒子が角張っているほど大 きい.

（5）液状化抵抗は粒子が丸くなるにしたがって小さく なる．また，形状が完全球の粒状体 $(F U=1.0)$ に対す る内部摩擦角および繰返し応力振幅比を比較すると動的 強さよりも静的強さのほうが粒子形状の影響を大きく受 ける.

以上のことより, 応力比が変化しない変形である等方 圧密あるいはせん断に伴い体積収縮を生じるせん断初期 の変形特性は粒子形状には無関係に土の状態を表す初期 間隙比あるいは余裕間隙比によって決まり，一方，正の ダイレイタンシーの大小に影響される内部摩擦角あるい は最大軸差応力や主応力比, および液状化抵抗などの強 度特性は粒子形状の影響を大きく受けるといえる．しか し，本研究が粒子破砕のない応力状態での結論であるの に対して, 実際の粗粒材を用いた大規模構造物ではかな りの粒子破砕を生じる可能性があり, 材料の硬さが等し い粒状体でも, その形状が異なるときには, 圧密時, 女 ん断時の破砕量が異なることが予想できるので，今後は 変形, 強度, ダイレイタンシー関係なよ゙に与える粒子の 破砕の影響を検討するつもりである.

謝辞：本研究を行うにあたり, 名古屋工業大学 松岡 元教授, 東京大学生産技術研究所 龍岡文夫教授, 北海 道大学工学部 三浦均也助教授, 高松工業高等専門学校 土木工学科 土居正信助教授には有益な御助言と御指導 をいただきました。ここに, 感謝の意を表する次第です.

\section{参 考 文 献}

1）三笠正人：土の工学的性質の分類表とその意義, 土と基 礎, Vol.12, No.4, pp. 17〜24, 1964.

2) 土質工学会：ロックフィル材料の試験之設計強度, 1982. 10.

3）土質工学会：粗粒材料の変形と強度, 1986.5.

4）三浦均也 - 長谷川敬寿 - 松本吉英 $\cdot$ 土岐祥介 : 砂の力学 的性質に及ぼす粒子形状および粒度分布の影響, 北海道 大学工学部研究報告, 第 149 号, pp. 11 24, 1991.2.

5）前田健一・古川美典・三浦均也・中田浩二 ・ 土岐祥介： 一次性質の異なる砂の変形・破壊挙動の拘束圧依存性, 第 27 回土質工学研究発表会発表講演集, pp. 623 626, 1992. 6.

6）たとえば, 豊田光雄・藤沢㑆彦 : 粗粒材料の内部摩擦角 における力学的要因の実験的検討, 第 27 回土質工学研究 発表会発表講演集, pp. 595～596，1992.6. 
7）吉村優治・小川正二：粒状体の間隙比およびせん断特性 に及ぼす一次性質の影響, 土木学会論文集, No.487/开 -26, pp. 99 108, 1994.3.

8) Wong,R.T., Seed,H.B. and Chan,C.K. : Cyclic Loading Liquefaction of Gravelly Soils, Proc. of ASCE, Vol.101, No.GT6, pp.571 -583, 1975.6.

9）吉見吉昭：砂地盤の液状化（第二版），技報堂，pp.19～ 67, 1991. 5 .

10) Hatanaka, M., Sugimoto, M.and Suzuki, Y. : Liquefaction Resistance of Two Alluvial Volcanic Soils Sampled by In Situ Freezing, Soils and Foundations, Vol.25, No.3, pp.49 $\sim 63,1985.9$.

11) Wadell, H. A. : Volume, Shape and Roundness of Rock Particles, Jour. Geol., Vol.40, pp.443 451, 1932.

12) Lees,G. : A New Method for Determining the Angularity of Particles, Sedimentology, 3, 1964.

13) Krumbein, W.C. : Measurement and Gelogic Significance of Shape and Roundness of Sedimentary Particles, J.Sed.Petrol., 11, pp.64 72, 1941.

14）吉村優治・小川正二：砂のような粒状体の粒子形状の簡 易な定量化法, 土木学会論文集, No. $463 /$ III -22 , pp. 95 103, 1993.3.

15）土質工学会：土質試験の方法と解説, pp. 54 67, 1990.3.

16）中村博久 - 脇阪良男：砂粒子表面の微視的特性亡強度特 性, 第25回土質工学研究発表会発表講演集, pp. 759 760, 1990. 6.

17）たとえば，土質工学会・飽和砂の非排水繰返し三軸試験 方法に関する研究委員会：委員会報告 I, 土の非排水繰 返し三軸試験方法に関するシンポジウム発表論文集, pp. 1 53, 1988. 12 .

18）福本武明：粒子破砕の程度を示す指標, 土と基礎, Vol.29, No.12, pp. 64 65, 1981. 12 .

19）三浦哲彦：高圧下の砂の応力〜ひずみ関係に関する一考 察, 土木学会論文報告集, No. 282, pp. 127 130, 1979. 2.

20）三浦均也・土岐祥介・長谷川敬寿 : 粒度組成の異なる砂
の変形・破壊挙動, 第 24 回土質工学研究発表会発表講演 集, pp. 539〜542, 1989.6.

21）龍岡文夫：「非常にゆるい砂」の非排水七ン断特性につい ての一考察, 土質工学会論文報告集, Vol.15, No. 3, pp. 93 95, 1975.

22）最上武雄: 土質力学, 技報堂, pp. 893 1036, 1969.8.

23) 足立紀尚・龍岡文夫：新体系土木工学 18 土の力学( III), 技報堂出版, pp. 61 83, 1981.8.

24）松岡 元 ·加藤正司・滝脇泰勝：乾燥状態と水で濡らし た状態のアルミ棒積層体の低拘束圧下のせん断強度の微 視的考察, 土木学会第 48 回年次学術講演会講演概要集 (III), pp. 868 869, 1993.9.

25) Isihara, K. and Watanabe, T. : Sand Liquefaction Through Volume Decrease Potential, Soils and Foundations, Vol.16, No.4, pp.61 70, 1976.12.

26) Rowe, P.W. : The stress-dilatancy relation for static equilibrium of an assembly of particles in contact, Proc. Royal Soc., London, Series A, Vol.269, pp.500 527, 1962.

27) Oda, M. : The Mechanium of Fabric Changes during Compressional Deformation of Sand, Soils and Foundations, Vol.12 No.2 pp.1 18, 1972.6

28）吉村優治：濃尾平野の水成堆積砂の物理的性質について, 第5回地盤工学シンポジウム論文集, 土質工学会中部支部, pp.89 94, 1993.7.

29) Seed, H.B. and Lee, K.L. : Liquefaction of Saturated Sands during Cyclic Loadings, Proc. of ASCE, Vol.92, No.SM6 pp.105 134, 1966.11.

30）小川正二 ·三井澄夫・和田 正 : 飽和砂の液状化への変 動セン断応力および過圧密の影響, 土質工学会論文報告 集, Vol.16, No.4, pp.77〜83, 1976.12.

31）吉村優治：飽和砂の非排水繰返し三軸試験における液状 化判定について, 岐皁高等專門学校紀要, 第 24 号, pp.5 $\sim 9,1989.2$.

(1993.6.10 受付)

\section{THE INFLUENCE OF GRAIN SHAPE ON ISOTROPIC CONSOLIDATION AND SHEAR CHARACTERISTICS OF SANDS}

\section{Yuji YOSHIMURA and Shoji OGAWA}

To explicate how the grain shape of sand can influence its isotropic consolidation and shear characteristics, an isotropic consolidation test, a drained triaxial test and a cyclic undrained triaxial test had been carried out on materials whose particle size and grain size distribution are the same but grain shapes are different. From these tests it appeared that the shape differences have a great influenceon the angle of internal friction, the dilatancy characteristics, and the liquefaction resistance ; and that the compression index when the sand is isotropically consolidated is uniquely determined by the initial void ratio, and the modulus of deformation indicating the rigidity in the early stage of the shearing by the volume decrease potential. 